\title{
A Study of Climate Variability and Socioeconomic Impact on
}

\section{Tourism Industry of Nepal}

\author{
Raju Pokharel ${ }^{1}$, Jagdish Poudel ${ }^{2}$, Aseem Raj Sharma ${ }^{3 *} \&$ Robert K Grala $^{1}$ \\ ${ }^{1}$ Mississippi State University, Starkville MS, USA \\ ${ }^{2}$ Auburn University, Auburn AL, USA \\ ${ }^{3}$ University of Northern British Columbia, Prince George BC, Canada \\ *Aseem Raj Sharma, E-mail: asharma@unbc.ca
}

Received: November 9, 2016 Accepted: November 22, 2016 Online Published: December 2, 2016

doi: $10.22158 /$ se.v2n1p20

URL: http://dx.dx.doi.org/10.22158/se.v2n1p20

\begin{abstract}
In Nepal, tourism is the second largest industry after agriculture. Furthermore, Nepal offers numerous opportunities for adventurous outdoor recreation, especially in the Himalayas, and attracts tourists from all over the World. However, future prosperity of Nepal's tourism industry might be affected by a changing climate and a socioeconomic environment. A log-level regression model is employed to estimate the impact of climatic and socioeconomic factors on the number of international tourists visiting Nepal. Climatic estimates indicated that an increase in temperature did not have a significant impact on the numbers of international tourist arrival. Results show that the number of international tourists visiting Nepal was positively associated with GDP and population growth, inflation rate, and an exchange rate. These results help policy makers for facilitating growth of tourism industry and its adaptability to climate change in Nepal.
\end{abstract}

Keywords

climate change, Himalayas, outdoor recreation, socioeconomic impacts, tourism

\section{Introduction}

Tourism is one of the largest industries in Nepal that employed 275,000 people in 2004 and generated 9.1\% of country's foreign cash inflows (Nyaupane \& Chhetri, 2009). Tourism generated US\$ 377.2 million of foreign exchange earnings in 2009 (Central Bureau of Statistics, 2012) which corresponded to $2.93 \%$ of the Gross Domestic Product (GDP) (The World Bank, 2013; Central Bureau of Statistics, 2012). This value reflects the contribution to the national economy only in terms of foreign exchange and does not account for direct, indirect, and induced impacts of domestic tourism. Hence, the total economic impact of tourism industry in Nepal may be even greater. Diverse landscape features such tall snow-capped mountains, waterfalls, unique plant and animal species, and pristine scenic beauty attract 
nature lovers, wildlife enthusiasts, and adventure seekers from around the World.

Tourism plays an important role in Nepal's economy which has been recognized by various policy incentives implemented to promote tourism industry and stimulate growth of other economy sectors. Different policy initiatives initiated by Nepal such as Visit Nepal 1998, Nepal Tourism Year 2011, and Nepal's Economic Summit 2014 suggested that there is an opportunity and urge for economic growth by investing in tourism sector. However, despite increased attention and policy incentives, tourism industry in Nepal has not performed as expected and did not reach the goal of increasing the annual number of international tourists to one million by 2011 (eTurboNews, 2012). Several factors such as socioeconomic, political, and climate-related factors might have contributed to this trend.

Numerous studies have been conducted to identify factors affecting tourism activities and to quantify their impact. Many of these studies have focused on socioeconomic factors, whereas other examined potential impacts of climate-related factors. Hamilton, Maddison and Tol (2005) conducted a simulation study to project the effect of population growth rate, per capita income, and climate change related factors (temperature and movements of a coast line) on the number of international tourists visiting Alps. They concluded that international tourism was likely to concentrate in areas that are economically more developed, with better infrastructure, and requiring less travel time. They further stated that climate change might shift winter recreational destinations further north or to higher altitudes. Song, Wong and Chon (2003) reported that economic parameters such as income elasticity and price elasticity have an impact on the number of tourists arriving in Hong Kong. They found that people with lower income were looking for less costly destinations. Countries with higher exchange rate between local currency and US dollar were financially more attractive to potential visitors.

Tourism and outdoor recreation are most important and rapidly growing service industries in the Himalaya region, but this industry is climate dependent (Smith, 1990). Previous studies have increasingly emphasized potential effects of climate change on tourism and corresponding economic impacts, as climate and weather patterns play an important role selecting travel destinations (Berrittella, Bigano, Roson, \& Tol, 2006; Hamilton et al., 2005). Climatic variables such as temperature, rainfall, fog, wind, and humidity may affect level of outdoor recreational activities and derived benefits (Goswami, Venugopal, Sengupta, Madhusoodanan, \& Xavier, 2006; Gómez Martín, 2005; Nicholls, 2004). Raise in a global temperature has changed the climatic conditions around the world (IPCC, 2013; Solomon, 2007). However, the exact impact of climate change on tourism might be difficult to determine because it might lead to a decline in some outdoor recreation activities while increasing the level of other activities (Mendelsohn, 2004).

Several studies suggested that winter travel destinations might be negatively affected due to higher temperatures and less snowfall (McCarthy, 2001). For example, study by Mendelsohn (2004) showed that a 2.5 degrees Celsius increase in temperature and $7 \%$ increase in rainfall would increase fishing and boating activities while decreasing skiing, camping and wildlife watching activities. Similarly, 1988 drought-related wildfire in Yellowstone National Park reduced the number of visitors by $15 \%$ and 
resulted in a loss of US\$S60 millions (Franke, 2000). Such reduction in wildlife recreation activities affect the local economy (Poudel et al., 2016a; Poudel et al., 2016b). Lise and Tol (2002) showed that global warming could alter holiday patterns in Europe by tourists seeking different holiday destinations or travelling at different times of the year. Time series analysis by Burakowski, Wake, Braswell and Brown (2008) found that increased temperature would have negative impacts on winter recreation such as winter skiing and snowmobiling. However, the analysis also indicated a positive impact on tourism in northern countries such as Canada. For example, Jones and Scott (2006) found that warm weather and lengthened season will increase number of visitors in Canada's National Parks. They projected that annual visitations in Canada's National Parks will increase by $6-10 \%$ by the 2020 due to temperature increase.

Although there is abundance of literature on impacts of climate change on tourism in various regions of the World, studies on climate change impacts on tourism in Nepal is limited. While few studies (for example, Nepal, 2011; Nyaupane \& Chhetri, 2009; Alam \& Regmi, 2004) examined the effect of climate change on Nepal's tourism industry. However, these studies focused on descriptive analyses and only suggested the possibility of impacts of climate change on tourism. Hence, studies using both the socioeconomic and climatic variables to estimate the impact on tourism industry are scant. Therefore, the goal of this study was to address this knowledge gap by estimating the impacts of socioeconomic and climatic factors on tourism in Nepal. The study quantifies the impacts on tourism in Nepal by analyzing climatic data from 1971 to 2009. The study helps to understand the relationships between socioeconomic and climatic trends, and number of international tourists visiting Nepal. The results will helpful to decision-makers in designing new policy tools and improving adaptation of Nepalese tourism industry to climate change.

\section{Method}

\subsection{Study Area}

Nepal is a Himalayan country located between India and China in the middle of the Hindu-Kush Himalayan Range that extends from the Afghanistan in east to Myanmar in west. Mount Everest, a world's tallest peak, is located in northern part of the country bordering the Tibetan plateau. Nepal occupies a total land area of 147,181 square kilometers $\left(\mathrm{km}^{2}\right)$ and has a population of 26.5 million (Central Bureau of Statistics, 2012). The southern portion of Nepal is a low land with a humid subtropical climate, whereas higher mountainous areas have a climate ranging from a highland sub-tropical to alpine (Peel, Finlayson, \& McMahon, 2007) and has diverse forest management activities (Rana et al., 2012). Nepal has distinct dry and wet seasons and more than $80 \%$ of rainfall occurs during monsoon season from June to September. Temperature is above freezing level for most parts of the country. 


\subsection{Data}

The study used publicly available data published by the World Bank, Nepal Tourism Board (NTB) and Department of Hydrometeorology (DHM). Economic data on GDP, inflation, exchange rate, and foreign income was obtained from an online data catalog for Nepal provided the World Bank and encompassing a period from 1901 to 2009 (The World Bank, 2013). Historical climate data, including average annual temperature and rainfall, was obtained from DHM's online portal as Regional Climate Models (RCMs) downscaled to $12 \times 12 \mathrm{~km}$ resolution monthly data starting from 1971 (Department of Hydrometeorology, 2011). Annual estimates of international tourists visiting Nepal during 1962-2009 were obtained from an online database maintained by Nepal Tourism Board (Nepal Tourism Board/Government of Nepal, 2012b). Due to availability of climatic data, the study period was limited to 39 years from 1971 to 2009 .

\subsection{Model Specification}

The temporal trend in mean air temperature and rainfall were calculated using non-parametric Man-Kendall trend test (Equation 1) (Burn \& Elnur, 2002; Kendall, 1975; Mondal, Kundu, \& Mukhopadhyay, 2012), whereas the magnitude of the trend was determined using Theil Sen estimator (Equation 2) ((Burn \& Elnur, 2002; Kendall, 1975; Mondal, Kundu, \& Mukhopadhyay, 2012; Sen, 1968):

$$
\sum_{i=1}^{n-1} \sin \left(x_{i+1}-x_{i}\right)
$$

where

$$
\operatorname{sgn}(\Delta x)=\left\{\begin{array}{c}
+1, x>0 \\
0, \Delta x=0 \\
-1, \Delta x \times 0
\end{array}\right.
$$

where $\mathrm{S}$ is Man-Kendall trend test statistics, $\mathrm{X}_{\mathrm{i}}$, is a monotonically increasing time series with time index $\mathrm{i}$, and $\operatorname{sign}(\Delta \mathrm{x})=+1$ if $(\Delta \mathrm{x})>0, \operatorname{sign}(\Delta \mathrm{x})=0$ if $(\Delta \mathrm{x})=0$, and $\operatorname{sign}(\Delta \mathrm{x})=-1$ if $(\Delta \mathrm{x})<0$. Trend magnitude was calculated as median of $\mathrm{m}_{\mathrm{k}}$ obtained from equation 2 .

$$
m_{\mathrm{L}}=\frac{\left(y_{f}-y_{2}\right)}{\left.f_{t_{f}}-t_{\mathrm{L}}\right)}
$$

where, $y$ is the climate variable at time $t$ and $i=1, \ldots, n$.

A log-linear regression model was constructed to estimate the impact of climatic and socioeconomic parameters on the number of international tourist visiting Nepal. The model was specified as follows:

$$
\log \left(Y_{i}\right)=\beta_{0}+X_{i} \beta+\mu_{l}
$$

where $Y_{\mathrm{i}}$ is a dependent variable representing the number of international tourist visiting Nepal in a given year, $\mathrm{X}_{\mathrm{i}}=1 * \mathrm{~K}$ vector of explanatory variables including climatic and socioeconomic variables, and $\beta$ is a $K^{*} 1$ vector of parameter estimates. The model assumed the errors $\left\{\mu_{\mathrm{i}}: \mathrm{i}=1,2 \ldots \mathrm{N}\right\}$ and $\mathrm{E}\left(\mu_{\mathrm{i}}\right)=0$ and 
$\operatorname{Var}\left(\mu_{\mathrm{i}}\right)=\sigma^{2}$ (Greene, 2008; Wooldridge, 2010). Based on selected climatic and socioeconomic variables the model was further specified as follows:

Ln $($ Tourist $)=\beta 0+\beta 1$ Rain $+\beta 2$ Temp $+\beta 3$ GDP $+\beta 4$ Pop $+\beta 5$ Inflation $+\beta 6$ Rate $+\beta 7$ Remm $+\beta 8$ Safety 4 where Tourist represents the number of international tourist visiting Nepal in a given year, Rain represents average annual rainfall in millimeters, Temp is the average annual temperature in degree celsius, GDP represents the Gross Domestic product in 2012 US\$ billion, Pop stands for the population growth rate, Inflation represents the inflation, Rate represents official exchange rate (LCU per US\$, period average), Remm represents the net foreign income in US\$ millions, and Safety indicates the number of battle-related casualties in a given year. Description of variables and corresponding descriptive statistics are presented in Table 1. Heteroscedasticity consistent standard errors were used to eliminate the possibility of unequal variances in the model. Heteroscedasticity consistent (White's) standard errors are reported in Table 3. Durbin-Watson test was performed to test if the residuals from the linear regression follow first order autocorrelation (Heij, De Boer, Franses, Kloek, \& Van Dijk, 2004).

\section{Result}

There has been a steady growth in the number of international tourists visiting Nepal since 1971 with a sharp drop observed during 2002-2003 after which visits started to increase again (Figure 1). The largest number of tourists was reported in $2007(526,705)$, whereas the lowest in $1971(49,914)$. The number of international tourists visiting Nepal between 1971 and 2009 averaged to 273,763 per year.

Table 1. Explanation of the Variables Used for Their Impact Analysis in the Tourism Industry in Nepal during 1971-2009 and Descriptive Statistics

\begin{tabular}{|c|c|c|c|c|c|c|}
\hline Variable & Variable Description & $\mathrm{N}$ & Mean & $\mathrm{SD}$ & Max & Min \\
\hline Tourist & Number of International Tourists & 39 & 273763 & 139413 & 526705 & 49914 \\
\hline Rain & Average Annual Rainfall in mm & 39 & 1654.94 & 159.23 & 1937.00 & 1331.41 \\
\hline Temp & Average Annual Temperature in degree Celsius & 39 & 18.87 & 0.53 & 20.36 & 17.75 \\
\hline$G D P$ & GDP (current billion US\$) & 39 & 4.24 & 3.02 & 12.85 & 0.88 \\
\hline Inflation & Inflation, GDP deflator (annual \%) & 39 & 8.80 & 5.93 & 27.52 & -3.56 \\
\hline \multirow[t]{2}{*}{ Remm } & & 39 & 20.34 & 37.21 & 152.84 & -22.82 \\
\hline & Net income from abroad (current million US\$) & & & & & \\
\hline Pop & Population growth (annual \%) & 39 & 2.13 & 0.40 & 2.59 & 1.12 \\
\hline Rate & $\begin{array}{l}\text { Official exchange rate (LCU per US\$, period } \\
\text { average) }\end{array}$ & 39 & 39.01 & 26.20 & 77.88 & 10.13 \\
\hline Safety & Battle-related deaths (number of people) & 39 & 254.05 & 728.45 & 3947.00 & 0.00 \\
\hline
\end{tabular}

Note. SD: Standard Deviation; N: Number of observations. 


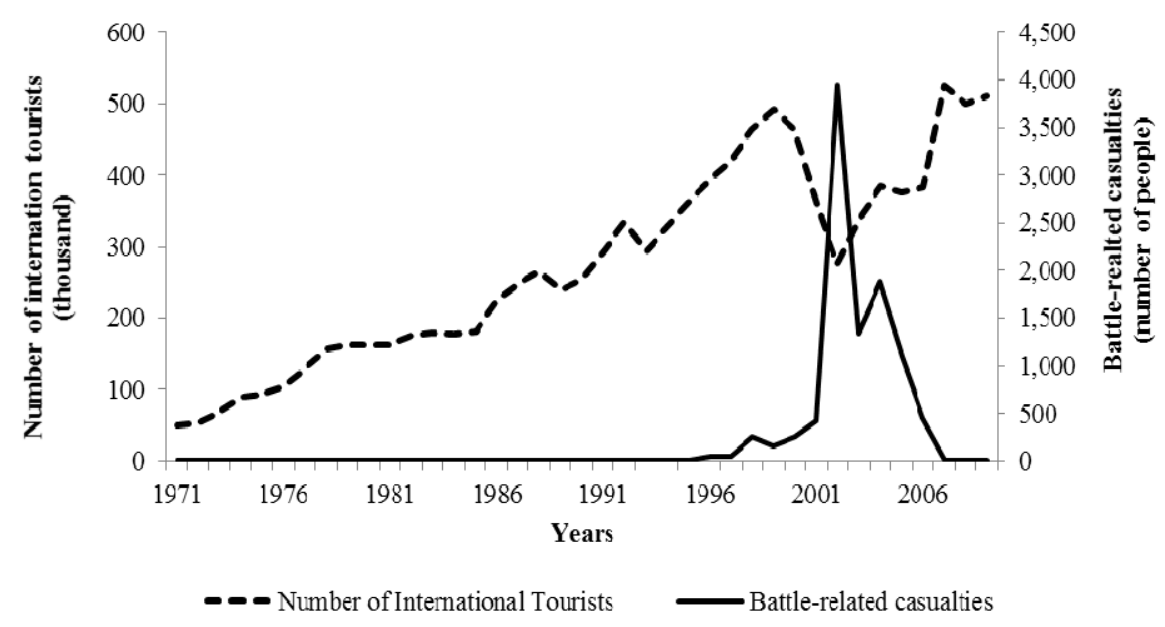

Figure 1. Total Number of International Tourists Visiting Nepal and Number of Battle-Related Casualties during 1971-2009

Nepal's economy, measured by GDP, has been continuously growing since 1971 reaching US $\$ 12.85$ billion in 2009 (Figure 2). Foreign income level from trade, remittance, and other sources was almost constant till 2000. It dropped substantially during 2002-2003 and started to grow exponentially after 2004 (Figure 2).

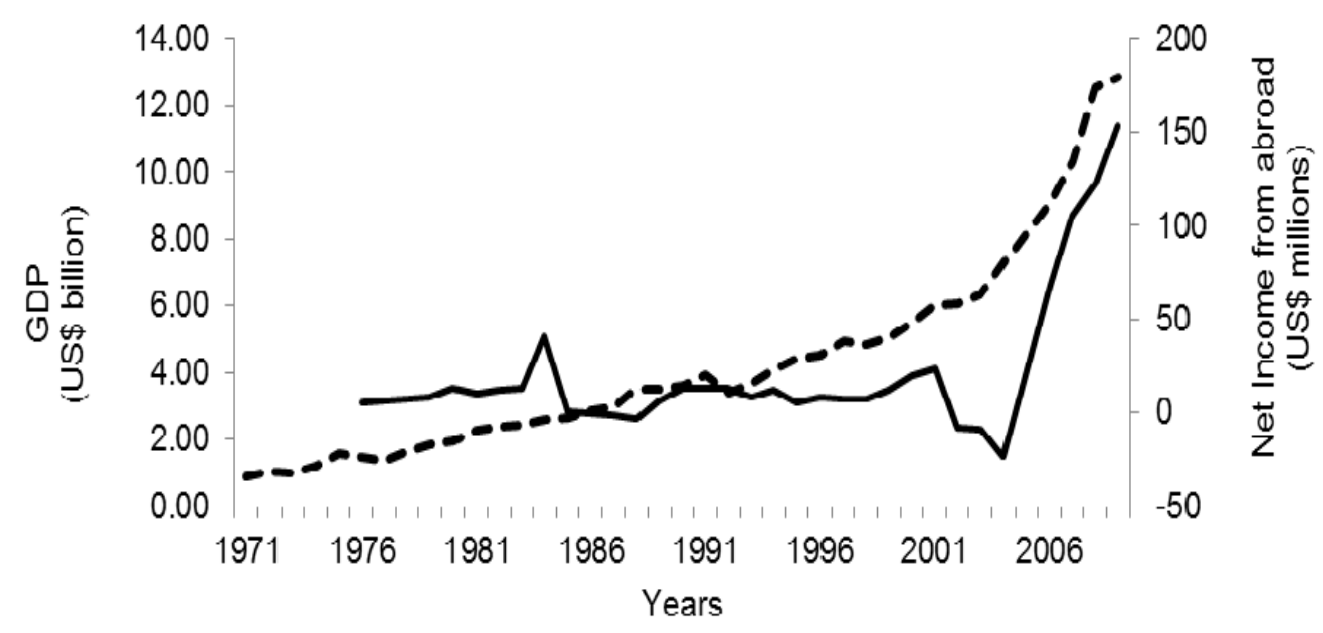

- - GDP (current US\$) - Net income from abroad

Figure 2. Nepal's Gross Domestic Product (GDP) and Net Income from Aboard during 1971-2009 
A net value of foreign income added to Nepalese economy reached $\$ 152.84$ million in 2009. The average population growth during 1971-2009 was 2.13\%. The largest growth rate was reported in 1994 (2.59\%). Since then, growth rate has slowly declined with the smallest value of $1.12 \%$ reported in 2009 (Figure 3).

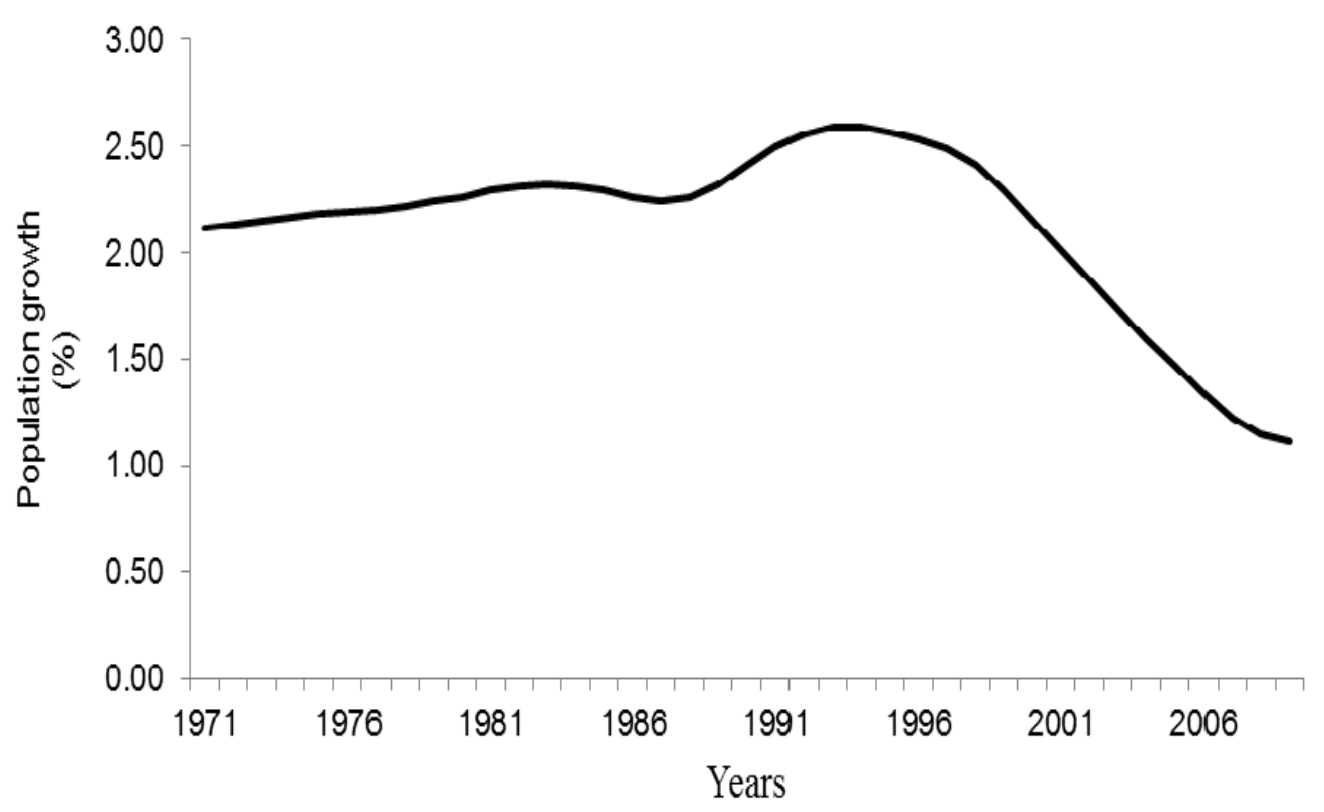

Figure 3. Population Growth Rate Reported for Nepal during 1971-2009

The highest level of inflation was observed in 1975 (27.52\%) and the lowest at $-3.56 \%$ (deflation) in 1977 (Figure 4). The average annual inflation rate during study period was $8.80 \%$. The exchange rate of Nepalese currency with US dollar stayed fairly constant till 1980's, after which it grew rapidly till 2001. The exchange rate leveled off after 2001. The highest exchange rate was observed in 2009 when one US dollar was traded for 79 Nepalese Rupees. 


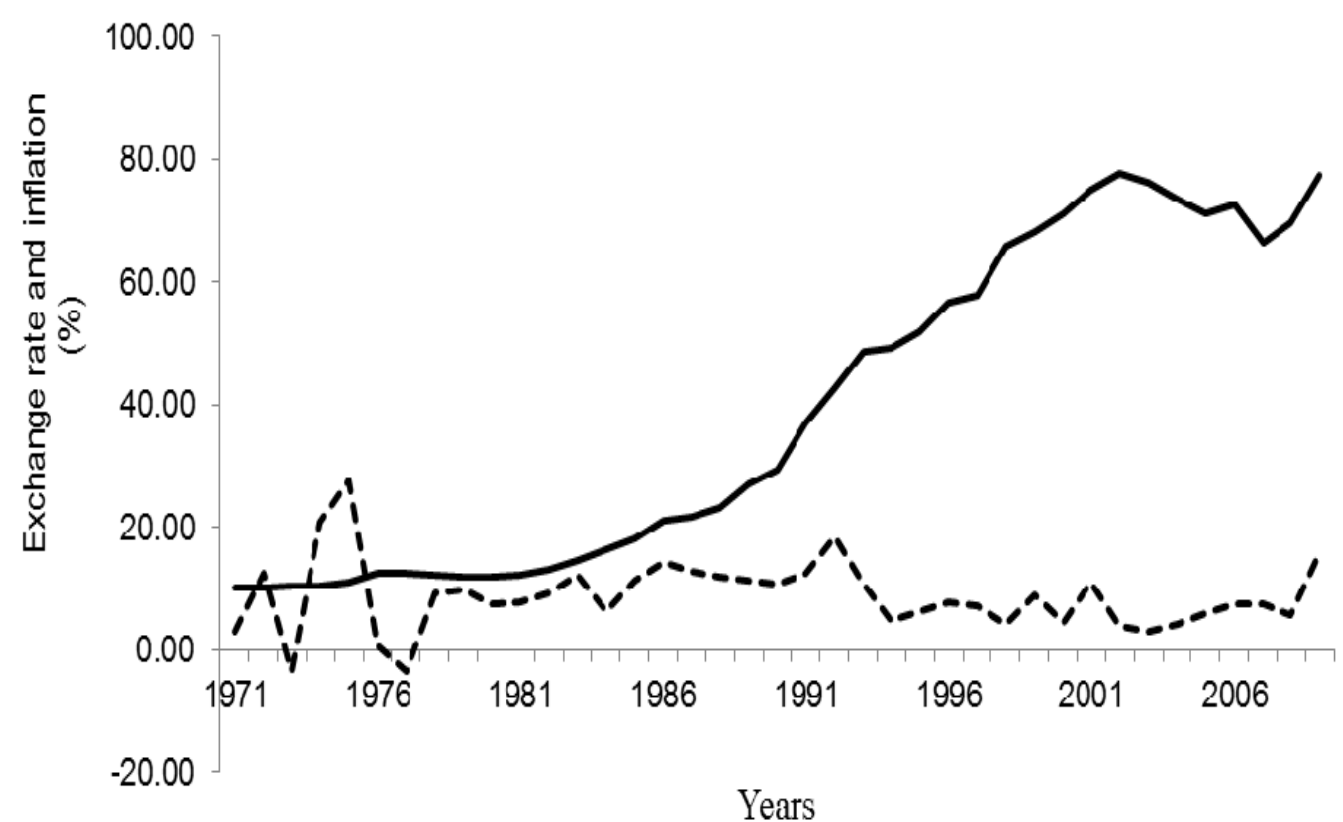

--nInflation Official exchange rate with US dollar

Figure 4. Inflation and Exchange Rate Reported for Nepal during 1971-2009

The average annual rainfall during the study period was 1654.94 millimeters (mm). The highest level of rainfall was reported in $1971(1937 \mathrm{~mm})$, whereas the lowest was reported in $1992(1331 \mathrm{~mm})$. Average annual temperature in Nepal during $1971-2009$ was $18.87^{\circ} \mathrm{C}$. The annual average maximum temperature was recorded in $2009\left(20.36{ }^{\circ} \mathrm{C}\right)$, whereas minimum was recorded in $1997\left(17.75{ }^{\circ} \mathrm{C}\right)$ (Figure 5). Mann-Kendall trend test indicated that there was not enough statistical significance to prove any trend in average annual rainfall $(p=0.943)$ and average annual temperature $(p=0.456)$ in Nepal. However, a Theil Sen's slope indicated a positive change in both climatic variables (Figures 5 and 6).

Table 2. Mann-Kendall Two Tailed Trend Test and Theil Sen's Slope Coefficients of Climate in Nepal during 1971-2009

\begin{tabular}{lllllll}
\hline Variable & Mean & Mann-Kendall & Var(S) & p-value & Sen's \\
& & S-value & slope \\
\hline Average Annual Rainfall in mm & & 1654.937 & 7.000 & 0.000 & 0.943 & 0.365 \\
$\begin{array}{l}\text { Average Annual Temperature } \\
\text { Celsius }\end{array}$ & & & & & & \\
\hline
\end{tabular}

A positive change of $0.06{ }^{\circ} \mathrm{C}$ per decade was observed in annual average air temperature. Many recent annual temperature anomalies were positive. A 5 -year moving average showed a consistent increase in 
an average air temperature. A positive anomaly was recorded from 2007 to 2009, with highest anomaly observed in 2009. The average air temperature increased by about $0.24{ }^{\circ} \mathrm{C}$ from 1971 to 2009. Rainfall increased by $3.65 \mathrm{~mm}$ per decade during the study periods. Positive rainfall anomalies were recorded for 1984-1986, 1999-2001, 2007-2008.

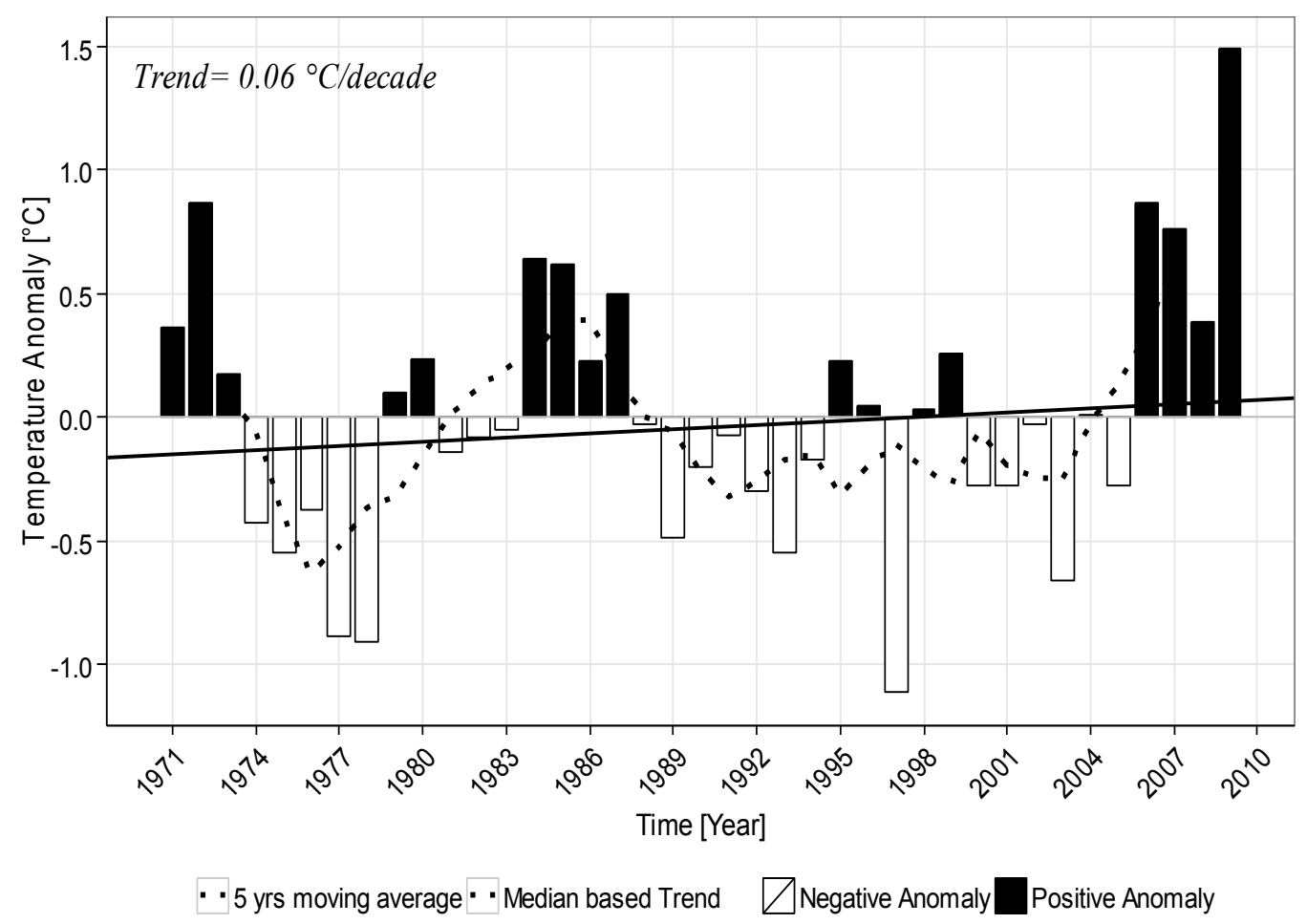

Figure 5. Average Annual Air Temperature Anomalies and Trend for Nepal during 1971-2009 


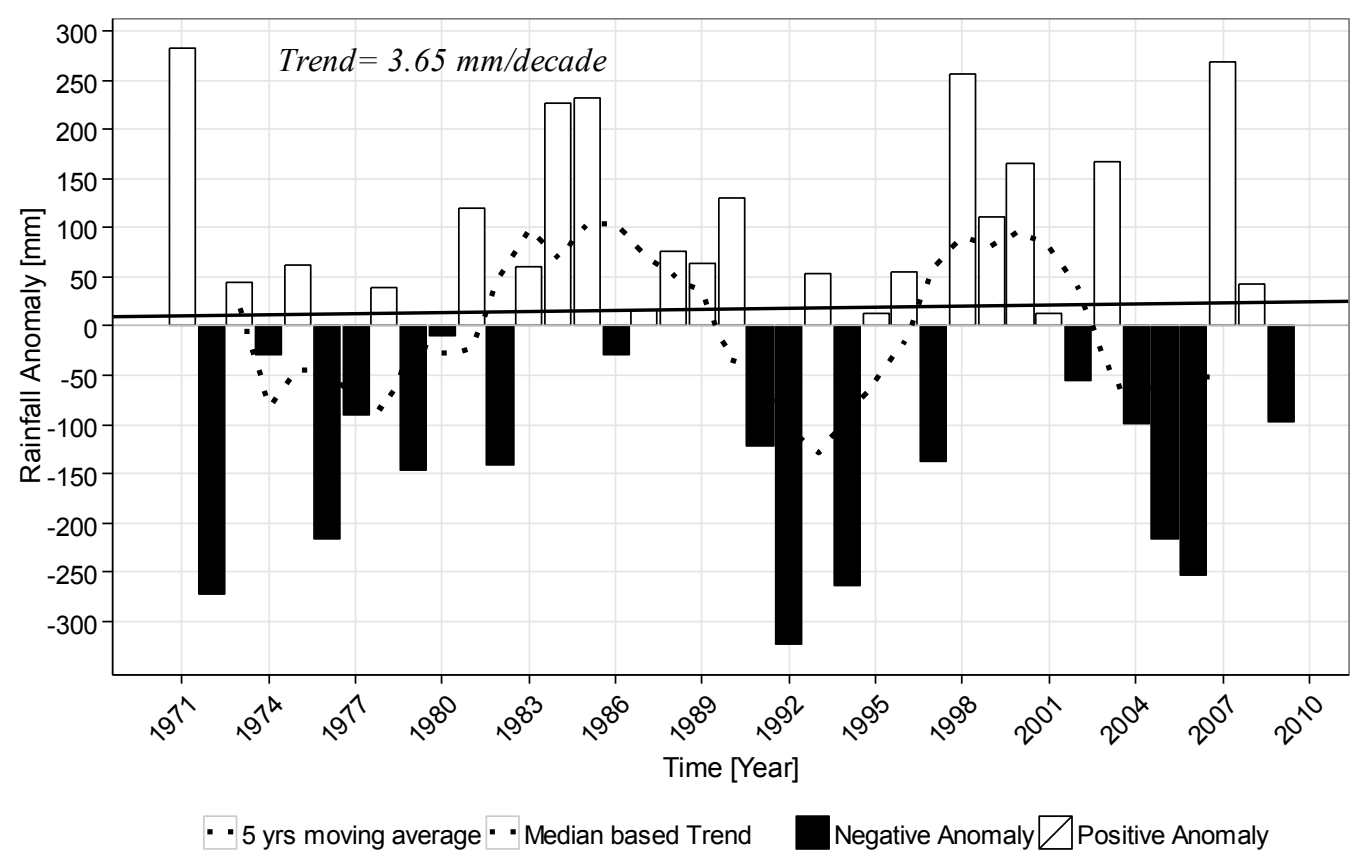

Figure 6. Annual Total Rainfall Anomalies and Trend with a 5-Year Moving Average in Nepal during 1971-2009

The regression analysis parameter estimates describing the impact climatic and socioeconomic factors are reported in Table 3. The model explained $95.62 \%$ of the variation in the number of international tourists visiting Nepal. Diagnostic test indicated that neither positive $(\mathrm{p}=0.2815)$ nor negative $(\mathrm{p}=0.7185)$ autocorrelation was not present in the model. The study indicated that an average annual rainfall had a positive effect on the number of international tourists visiting Nepal $(\mathrm{p}=0.06)$. An average annual temperature did not have any impact on number of tourists $(\mathrm{p}=0.36)$. GDP was significant in explaining the variation in number of international tourists $(p<0.0001)$. A one U.S.\$ billion added in Nepal's economy was associated with a $14.31 \%$ increase of international tourists visiting Nepal. Inflation ( $\mathrm{p}=0.051)$ and exchange rate $(\mathrm{p}=0.0003)$ had positive impact on the number of international tourists visiting Nepal. Inflation elasticity has positive effect on the number of international tourists Increase in exchange rate between Nepalese rupee and US dollar by one rupee increased number of international tourists by $1.00 \%$. Net income from abroad (remittance) and battle-related casualties had negative impact in tourism in Nepal. A one US\$ million increase in foreign income decreased the number of international tourists by $0.38 \%$. A one percent population growth rate increase was associated with a $43.55 \%$ increase the number of international tourists by $43.55 \%$ (Figure 3 ).

Table 3. Estimation of the Impact of Socioeconomic and Climatic Variables on Number of International Tourists Arriving in Nepal for the Period of 1971-2009 


\begin{tabular}{|c|c|c|c|}
\hline Variable & Variable Description & Estimate & HCSE \\
\hline Rain & Average Annual Rainfall in mm & $0.0002^{* * *}$ & 0.0001 \\
\hline Temp & Average Annual Temperature in degree Celsius & 0.0372 & 0.0396 \\
\hline$G D P$ & GDP (current billion US\$) & $0.1431^{*}$ & 0.0309 \\
\hline Pop & Population growth (annual \%) & $0.4355^{*}$ & 0.1011 \\
\hline Inflation & Inflation, GDP deflator (annual \%) & $0.0098^{* * *}$ & 0.0048 \\
\hline Rate & Official exchange rate (LCU per US\$, period average) & $0.0100^{*}$ & 0.0024 \\
\hline Remm & Net income from abroad (current million US\$) & $-0.0038^{*}$ & 0.0011 \\
\hline Safety & Battle-related deaths (number of people) & $-0.0001^{*}$ & 0.00002 \\
\hline Intercept & Constant & $9.4577^{*}$ & 0.8085 \\
\hline \multicolumn{2}{|c|}{ Durbin-Watson D-value } & \multicolumn{2}{|l|}{2.098} \\
\hline \multicolumn{2}{|l|}{ R-Square } & \multicolumn{2}{|l|}{0.9562} \\
\hline
\end{tabular}

${ }^{*}$ Significant at $p \leq 0.01 ;{ }^{* *}$ Significant at $p \leq 0.05 ;{ }^{* * *}$ Significant at $p \leq 0.10$.

HCSE: Heteroscedasticity Consistent Standard Error (White's Error).

\section{Discussion}

Previous analyses of climatic data indicated a significant increasing trend of temperature and rainfall in Nepal (Sharma, Shrestha, \& Bajracharya, 2013; Hua, 2009; Nepal Climate Vulnerability Study Team, 2009). Similarly, our analysis also showed anomalies with warmer and wet recent years. A trend analysis indicated an increase in temperature which was consistent with many national and regional studies suggesting that recent decades were warmer than any previous time period (Sharma, 2009; Nepal Climate Vulnerability Study Team, 2009; Nyaupane \& Chhetri, 2009). The observed increase in an average annual rainfall is consistent with the hypothesis that higher temperatures will lead to an increase in rainfall and might cause extreme weather events (Wentz, Ricciardulli, Hilburn, \& Mears, 2007; Barnett, Adam, \& Lettenmaier, 2005). However, warming rates determined in our study are lower than many reported air temperature increases. This discrepancy might be due to the coarse resolution data averaged over the whole country. The average annual rainfall increased over the study period with multiple years showing positive anomalies.

Climate has an impact on how tourists select travel destinations. Thus, variation in climate will affect not only travel destination choice but also tourism-dependent economy of that region (Berrittella, Bigano, Roson, \& Tol, 2006). Majority of tourists visit Nepal for its scenic and adventurous high mountains in remote Himalayans, trekking opportunities, and other mountain-related adventures. It is likely that tourists trekking and climbing mountains will be affected because of an increasing frequency of extreme weather events and declining of a snow line in Himalayas due to higher temperatures (Sharma, 2009). Trekking routes and popular mountain destinations in Nepal are located in remote area with limited facilities. Increasing temperature and rainfall levels might increase the likelihood of floods, 
landslides, and avalanches and, thus, increase risk for tourists and businesses associated with tourism. For example, recent avalanche on Mount Everest destroyed a base camp and initial reports indicated that 16 guides preparing a route for climbers died (Jenkins, 2014).

Other impacts of climate change include diseases, pests, and pathogens introduced to the mountain region which would increase the likelihood of contracting communicable diseases by tourists (IPCC, 2014; Sharma, 2009). Climate change resulting in limited water availability and higher food and lodging prices can make Nepal a relatively more expensive tourist destination compared to other countries. As a result, the number of tourists visiting Nepal might decrease which would have a negative impact on the economy.

An average annual rainfall had a positive impact on number of tourists indicating a clear tourist preference for water-based recreation. Nepal has a mountainous landscape and, therefore, attracts many tourists because of its free-flowing rivers and snow-covered peaks. Higher rainfall increases a snow cover and discharge in rivers. A better snow cover will promote mountaineering, sightseeing, skiing, trekking, and mountain expeditions, whereas a higher discharge in rivers will promote water-based recreation such as rafting, boating, and kayaking. However, temperature is considered the most important weather parameter for tourist travel and beyond a certain range it becomes unfavorable (Gössling \& Hall, 2006).

Change in rainfall is highly dependent on temperature change and a temperature increase induces more rainfall. However, this study failed to establish any significant impact of average annual temperature on the number of tourists visiting Nepal. A compelling explanation might be that tourists visit Nepal for various types of recreation and changing climate may inhibit certain type of outdoor activities, while facilitating other types (Jones \& Scott, 2006; Mendelsohn, 2004; Lise \& Tol, 2002). More research using high resolution climate data and advanced economic modeling is needed to derive more precise impact estimates on various types of outdoor activities. Further, our study accounted only for international tourists. Inclusion of domestic tourists might yield different estimates. While there is uncertainty related to the impact of climate change on tourism, several studies have suggested that impact of climate change might substantially smaller than the impact of socioeconomic factors such as population and economic growth (Hamilton, Maddison, \& Tol, 2005). A growing economy is, therefore, a healthy sign for a developing tourism in changing climatic conditions for such countries as Nepal.

With the collapse of a carpet trade at the end of 1990s (Becker, 2011; Gurung, 2011), remittance became the major source of foreign income. More money coming from abroad affected tourism industry mainly in two ways. First, labor cost and good prices in local markets increased which resulted in higher operating costs of a tourism industry. Second, supply of manpower for tourism industry decreased because many people moved out to work in other countries. Another important and significant factor affecting the number of international tourists was the exchange rate. A higher exchange rate makes goods and services less costly relative to other countries and thus increases the competitiveness of Nepal's tourism industry. Population growth was another important factors as it 
affects labor availability needed to support tourism industry. Observed population patterns showed that population growth rate can serve as a positive indicator for increasing number of international tourists visiting Nepal.

\section{Conclusions}

Tourism is one of the most important industries in Nepal that heavily relies on international tourists. Our study indicated that the number of international tourists visiting Nepal has positive relation with both on climatic and socioeconomic factors. Therefore, changing climate is likely to alter future recreation patterns and contribution of tourism industry to Nepal's economy. Our climate data analysis was, however, limited by a very coarse data resolution which might affected model estimates. Other studies indicated that in fact socioeconomic factors might have a greater impact on tourism than climate change-related factors. While our results will be helpful in guiding future policies related to tourism in Nepal in general, a further research is needed to quantify the impact of climatic and socioeconomic impacts on individual outdoor activities and develop policy measures promoting most viable recreation activities.

\section{References}

Alam, M., \& Regmi, B. R. (2004). Adverse Impacts of Climate Change on Development of Nepal: Integrating Adaptation into Policies and Activities. Capacity Strengthening in the Least Developed Countries (LDCs) for Adaptation to Climate Change (CLACC) (No. 3), (p. 38). Dhaka. Retrieved from http://www.forestrynepal.org/publications/reports/252

Barnett, T. P., Adam, J. C., \& Lettenmaier, D. P. (2005). Potential impacts of a warming climate on water availability in snow-dominated regions. Nature, 438(7066), 303-309. https://dx.doi.org/10.1038/nature04141

Becker, D. (2011). Tattered: Why the Tibetan Carpet Industry of Nepal Is Declining, and How To Mend It (No. 1235). Independent Study Project (ISP) Collection (pp. 1-29). Independent Study Project (ISP) Collection. Retrieved from http://www.digitalcollections.sit.edu/isp_collection/1235

Berrittella, M., Bigano, A., Roson, R., \& Tol, R. S. J. (2006). A general equilibrium analysis of climate change impacts on tourism. Tourism Management, 27(5), 913-924. https://dx.doi.org/10.1016/j.tourman.2005.05.002

Burakowski, E. A., Wake, C. P., Braswell, B., \& Brown, D. P. (2008). Trends in wintertime climate in the northeastern United States: 1965-2005. Journal of Geophysical Research, 113(D20), 1-12. https://dx.doi.org/10.1029/2008jd009870

Burn, D. H., \& Elnur, M. A. H. (2002). Detection of hydrologic trends and variability. Journal of Hydrology, 255(1-4), 107-122. https://dx.doi.org/10.1016/S0022-1694(01)00514-5

Central Bureau of Statistics. (2012). National Population and Housing Census 2011 (pp. 1-278). Retrieved from http://www.cbs.gov.np/?p=2017 
Department of Hydrometeorology/Government of Nepal. (2011). Technical Approach and Methodology for Projected Data Preparation (pp. 1-11). Kathmandu.

eTurboNews. (2012, January 2). Nepal tourism misses 1 million arrivals target. eTurboNews; eTN Global Travel Industry News. Retrieved from http://www.eturbonews.com/27171/nepal-tourism-misses-1-million-arrivals-target

Franke, M. A. (2000). Yellowstone in the Afterglow: Lessons from the Fires. Yellowstone Center for Resources, Yellowstone National Park.

Gómez Martín, M. B. (2005). Weather, climate and tourism a geographical perspective. Annals of Tourism Research, 32(3), 571-591. https://dx.doi.org/10.1016/j.annals.2004.08.004

Gössling, S., \& Hall, C. M. (2006). Uncertainties in Predicting Tourist Flows Under Scenarios of Climate Change. Climatic Change, 79(3-4), 163-173. https://dx.doi.org/10.1007/s10584-006-9081-y

Goswami, B. N., Venugopal, V., Sengupta, D., Madhusoodanan, M. S., \& Xavier, P. K. (2006). Increasing trend of extreme rain events over India in a warming environment. Science, 314(5804), 1442-1445. https://dx.doi.org/10.1126/science.1132027

Greene, W. H. (2008). Econometric Analysis (6th ed., Vol. 5, pp. 9-63). Prentice hall.

Gurung, T. D. (2011, June 10). The rise and fall of the Tibetan carpet industry. Nepali Times. Kathmandu. Retrieved from http://www.nepalitimes.com/news.php?id=18273

Hamilton, J. M., Maddison, D. J., \& Tol, R. S. J. (2005). The effects of climate change on international tourism. Climate Research, 29, 245-254. https://dx.doi.org/10.3354/cr029245

Heij, C., De Boer, P., Franses, P. H., Kloek, T., \& Van Dijk, H. K. (2004). Econometric Methods with Applications in Business and Economics (1st ed., pp. 118-180). Oxford University Press.

Hua, O. (2009). The Himalayas-Water Storage under Threat (No. Sustainable Mountain Development No. 56, ICIMOD, Winter 2009). Water Storage-A strategy for climate change adaptation in the Himalayas. Kathmandu.

IPCC. (2013). Climate Change 2013: The Physical Science Basics. Contribution of Working Group I to the Fifth Assessment Report of the Intergovernmental Panel on Climate Change (p. 1535). Cambridge, United Kingdom and New York, NY, USA: Cambridge University Press.

IPCC. (2014). Summary for policymakers. In C. B. Field, V. R. Barros, D. J. Dokken, K. J. Mach, M. D. Mastrandrea, T. E. Billier, ... L. L. White (Eds.), Climate Change 2014: Impacts, Adaptation, and Vulnerability. Part A: Global and Sectorial Aspects. Contribution of Working Group II to the Fifth Assessment Report of the Intergovernmental Panel on Climate Change (pp. 1-32). Cambridge University Press, Cambridge, United Kingdom and New York, NY, USA.

Jenkins, M. (2014). Sherpas end the Everest climbing season in Nepal. National Geographic News. $\begin{array}{llll}\text { Retrieved } \quad \text { September } & \text { 2014, from }\end{array}$ http://www.news.nationalgeographic.com/news/2014/04/140425-mount-everest-climbing-sherpasavalanche/ 
Jones, B., \& Scott, D. (2006). Climate change, seasonality and visitation to Canada's national parks. Journal of Park and Recreation Administration, 24(2).

Kendall, M. G. (1975). Rank Correlation Methods (4th ed.). London: Charles Griffin.

Lise, W., \& Tol, R. S. J. (2002). Impact of climate on tourist demand. Climatic Change, 55(4), 429-449. https://dx.doi.org/10.1023/A:1020728021446

McCarthy, J. J. (2001). Climate Change 2001: Impacts, Adaptation, and Vulnerability: Contribution of Working Group II to the Third Assessment Report of the Intergovernmental Panel on Climate Change. Cambridge University Press.

Mendelsohn, R. O. N. J. E. (2004). The Impact of Climate Change on the United States Economy. Cambridge: Cambridge Univ. Press.

Mondal, A., Kundu, S., \& Mukhopadhyay, A. (2012). Rainfall trend analysis by Mann-Kendall Test: A case study of North-Eastern part of Cuttack District. Orissa, 2(1), 70-78.

Nepal Climate Vulnerability Study Team. (2009). Vulnerability through the Eyes of the Vulnerable. Boulder, CO and Kathmandu, Nepal: Institute for Social and Environmental Transition (ISET), \& Institute for Social and Environmental Transition-Nepal (ISET-N), Nepal.

Nepal, S. K. (2011). Mountain tourism and climate change: Implications for the Nepal Himalaya. Nepal Tourism and Development Review, 1(1), 1-14.

Nicholls, S. (2004). Climate Change and Tourism. Annals of Tourism Research, 31(1), 238-240. https://dx.doi.org/10.1016/j.annals.2003.08.006

Nyaupane, G. P., \& Chhetri, N. (2009). Vulnerability to climate change of nature-based tourism in the Nepalese Himalayas. Tourism Geographies, 11(1), 95-119. https://dx.doi.org/10.1080/14616680802643359

Peel, M. C., Finlayson, B. L., \& McMahon, T. A. (2007). Updated world map of the Köppen-Geiger climate classification. Hydrology and Earth System Sciences, 11, 1633-1644. https://dx.doi.org/10.5194/hess-11-1633-2007

Poudel, J., Henderson, J. E., \& Munn, I. A. (2016a). Economic contribution of hunting expenditure to the southern United States of America. International Journal of Environmental Studies, 73(2), 236-254. https://dx.doi.org/10.1080/00207233.2016.1143701

Poudel, J., Munn, I. A., \& Henderson, J. E. (2016b). Economic contribution of wildlife watching recreation expenditures (2006 \& 2011) across the U.S. South: An input-output analysis. Journal of Outdoor Recreation and Tourism.

Rana, E., Karki, S., Karky, B., Kotru, R., \& Poudel, J. (2012). REDD+and forest governance in Nepal. In G. Broekhoven, H. Savenije, \& S. von Scheliha (Eds.), Moving Forward with Forest Governance (pp. 167-174). Tropenbos International, Wageningen, the Netherlands.

Sen, P. K. (1968). Estimates of the regression coefficient based on Kendall's Tau. Journal of the American Statistical $\quad$ Association, $\quad 63(324), \quad 1379-1389$. https://dx.doi.org/10.1080/01621459.1968.10480934 
Sharma, A. R. (2009). Community Vulnerabilities to Climate Change and Local Coping Mechanisms in Khudi Watershed. CDES, Tribhuvan University.

Sharma, A. R., Shrestha, A. B., \& Bajracharya, S. (2013). Climatological variability and trends in the Koshi River Basin, Nepal. Himalayan Journal of Development and Democracy, 8(250), 1-19.

Smith, K. (1990). Tourism and climate change. Land Use Policy, 7(2), 176-180. https://dx.doi.org/10.1016/0264-8377(90)90010-V

Solomon, S. (2007). Climate Change 2007-The Physical Science Basis: Working Group I Contribution to the Fourth Assessment Report of the IPCC (Vol. 4). Cambridge University Press.

Song, H., Wong, K. K. F., \& Chon, K. K. S. (2003). Modelling and forecasting the demand for Hong Kong tourism. International Journal of Hospitality Management, 22(4), 435-451. https://dx.doi.org/10.1016/S0278-4319(03)00047-1

The World Bank. (2013). Nepal|Data. Online Data Catalog. Retrieved August 18, 2014, from http://www.data.worldbank.org/country/nepal

Wentz, F. J., Ricciardulli, L., Hilburn, K., \& Mears, C. (2007). How much more rain will global warming bring? $\quad$ Science (New York, N.Y.), 317(5835), 233-235. https://dx.dx.doi.org/10.1016/S0278-4319(03)00047-1

Wooldridge, J. M. (2010). Econometric analysis of cross section and panel data. MIT press. 